\title{
Kelayakan Usaha Pengolahan Limbah Kulit Udang dan Rajungan (Studi di Kabupaten Situbondo dan Banyuwangi Provinsi Jawa Timur)
}

\author{
Prospect of Shrimp and Crab Shells Waste Processing Bussiness \\ (Study in Situbondo and Banyuwangi Regency East Java Province)
}

\author{
Ratna Dewi Judhaswati ${ }^{1 \otimes}$ dan Herna Octivia Damayanti ${ }^{2}$ \\ ${ }^{1}$ Badan Penelitian dan Pengembangan Provinsi Jawa Timur \\ ${ }^{2}$ Badan Perencanaan Pembangunan Daerah Kabupaten Pati
}

DOI: https://doi.org/10.32781/cakrawala.v12i2.253

\begin{tabular}{l}
\hline ARTICLE INFO \\
Kelayakan Finansial, \\
Kitin, \\
Limbah Laut, \\
Nilai Tambah, \\
Pupuk \\
Financial Feasibility, \\
Chitin, \\
Marine Waste, \\
Added Value, \\
Fertilizer \\
\hline
\end{tabular}

Article History:

Received : Oktober 2018

Accepted : December 2018

\begin{abstract}
Abstrak:
Selama ini hasil limbah laut yang berupa kulit udang, cangkang kerang, cangkang rajungan hanya dimanfaatkan sebagai campuran bahan terasi, makanan ternak dan juga untuk aksesoris, bahkan di beberapa daerah pesisir dibuang dan menimbulkan bau yang tidak sedap. Permasalahan yang dihadapi adalah limbah kulit udang dan rajungan sejauh ini belum dimanfaatkan untuk diolah menjadi produk yang memiliki nilai jual tinggi (dalam hal ini diolah menjadi pupuk dan kitin). Dengan demikian, maka diperlukan sebuah kajian tentang kelayakan finansial yang gunanya untuk melihat layak tidaknya pengolahan ini dilakukan dan juga perhitungan besarnya nilai tambah yang dihasilkan dari proses perubahan imbah kulit udang dan rajungan menjadi produk pupuk dan kitin, sehingga akan didapatkan gambaran besaran keuntungan perusahaan. Tujuan penelitian : (1) untuk menganalisis kelayakan finansial usaha dan (2) untuk menganalisis nilai tambah dan keuntungan perusahaan. Penelitian ini deskriptif dengan pendekatan kuantitatif dilakukan bulan Februari-September 2018 di Kabupaten Situbondo dan Banyuwangi. Informan penelitian berasal dari 2 kabupaten yaitu Kabupaten Situbondo 11 orang dan Kabupaten Banyuwangi 19 orang. Teknik pengumpulan data dengan Focus Group Discussion (FGD) dan pengisian kuesioner. Analisis data terdiri dari (1) analisis nilai tambah dan (2) analisis kelayakan finansial rasio $R / C$, $N P V$, IRR, PP. Hasil penelitian adalah (1) finansial usaha pengolahan limbah kulit udang dan rajungan menunjukkan bahwa usaha ini layak dijalankan dengan tingkat pengembalian hasil $35,05 \%$ dan periode pengembalian pengeluaran investasi 2,1 tahun. (2) Perhitungan nilai tambah pengolahan limbah kulit udang dan rajungan adalah $R p$ 382.375.200,-/tahun dengan rasio nilai tambah $75,151 \%$ dan marjin keuntungan perusahaan $77,430 \%$.

Abstract:

During this time marine waste in the form of shrimp shells, clam shells, crab shells are only used as a mixture of shrimp paste, livestock feed and also for accessories, even in some coastal areas are discarded and cause unpleasant odors. The problem faced is the waste of shrimp and crab shells so far has not been used to be processed into products that have high selling value (in this case processed into fertilizer and chitin). Thus, it is necessary to study the financial feasibility that is used to see whether or not this processing is feasible and also the calculation of the added value generated from the process of shrimp and crab shells waste into fertilizer and chitin products, so that a prediction of the amount of company profits. Research objectives: (1) to analyze the financial feasibility of the business and (2) to analyze the added value and profits of the company. This descriptive study with quantitative approach was held in February-September 2018 in Situbondo and Banyuwangi Regencies. Research informants came from 2 regencies, namely Situbondo Regency 11 people and Banyuwangi Regency 19 people. Data collection techniques with Focus Group Discussion and filling out questionnaires. Data analysis consists of (1) value added analysis and (2) financial feasibility analysis ratio of $R / C, N P V, I R R, P P$. The results of the study are (1) financial business of shrimp and crab shells waste processing shows that this business is feasible to run with a return rate of $35.05 \%$ and payback period of investment expenditure 2.1 years. (2) Calculation of added value of shrimp and crab shells waste processing is IDR 382,375,200/year with a value added ratio of $75.151 \%$ and company profit margin of $77.430 \%$.
\end{abstract}

Cite this as:

Judhaswati, R. D., \& Damayanti, H. O. (2018). Kelayakan Usaha Pengolahan Limbah Kulit Udang dan Rajungan (Studi di Kabupaten Situbondo dan Banyuwangi Provinsi Jawa Timur). Cakrawala, 12(2). 118-136. https://doi.org/10.32781/cakrawala.v12i2.253

\begin{tabular}{ll}
\hline Corresponding author : \\
Address $\quad$ Jl. Gayung Kebonsari No.56, Gayungan, Kota \\
\\
Email $\quad$ SBY, Jawa Timur 60235 \\
Phone $\quad:$
\end{tabular}




\section{Pendahuluan}

Provinsi Jawa Timur mempunyai wilayah laut seluas $110.764,28 \mathrm{~km}^{2}$. Data BPS tahun 2016, hasil produksi perikanan tangkap baik perikanan laut dan perikanan umum sebesar 407.814,6 ton sedikit lebih rendah dibanding tahun 2015 sebesar 416.529 ton (BPS Prov. Jatim, 2017). Salah satu potensi komoditas ekspor yang sangat besar yaitu kepiting dan udang. Tahun 2015 ekspor kepiting dan kerang-kerangan mencapai 109.624,4 ton, sementara komoditas udang sebesar 145.077,9 ton (BPS Prov. Jatim, 2016). Ada beberapa daerah di Jawa Timur yang menjadi sentra komoditas udang dam rajungan antara lain Gresik, Pasuruan, Tuban, Situbondo, Banyuwangi, Lamongan. Hal ini ditunjang dengan keberadaan tambak, coldstorage maupun perusahaan pengolahan udang baik skala kecil sampai skala besar terdapat di wilayah tersebut. Contoh, Kabupaten Situbondo selain tambak dari perusahaan juga terdapat tambak yang dikelola oleh masyarakat, sedangkan di Kabuptaen Banyuwangi mayoritas tambak merupakan milik dari perusahaan. Di Indonesia secara keseluruhan terdapat sekitar 170 unit industri pengolahan udang dengan kapasitas produksi mencapai 500.000 ton per tahun (Indrasti dkk, 2012).

Tingginya tingkat produksi udang dan ekspor udang dalam bentuk olahan menghasilkan produk samping berupa cangkang ataupun kepala udang. Chasanah dan Barus (1994) menemukan bahwa $40 \%$ bagian dari udang dapat dikonsumsi dan sisanya adalah cangkang dan kepala. Sismaraini (2015) menyebutkan bahwa dari sekitar 170 unit industri pengolahan udang dengan kapasitas produksi mencapai 500.000 ton per tahun tersebut dapat diestimasikan akan menghasilkan 300.000 ton limbah udang.

Selama ini hasil limbah laut yang berupa kulit udang, cangkang kerang, cangkang rajungan hanya dimanfaatkan sebagai campuran bahan terasi, makanan ternak dan juga untuk aksesoris, bahkan di beberapa daerah pesisir dibuang dan menimbulkan bau yang tidak sedap. Mengingat besarnya limbah/hasil samping tersebut, maka diperlukan inovasi teknologi dalam pengolahannya. Pengolahan kulit udang dan rajungan menjadi kitin dan kitosan merupakan bentuk inovasi dan berpeluang menghasilkan nilai tambah dari limbah buangan. Kitin dan kitosan merupakan sumber polimer terbarukan yang berasal dari kulit udang, kulit rajungan dan kulit famili crustacea lainnya yang memiliki manfaat besar dalam dunia pertanian, industri kimia, kesehatan dan makanan.

Hasil temuan di lapangan memperlihatkan bahwa manfaat kitosan secara umum dapat digunakan untuk pengawet alami berbagai produk pangan seperti bakso, sosis, nuget, jus buah/sayur, tahu, ikan asin, mie basah, produk olahan ikan, buah-buahan, mayonise, dodol, dll karena memiliki aktifitas antimikroba dan antioksidan. Kitin dan Kitosan juga bermanfaat dalam bidang pertanian sebagai promotor pertumbuhan tanaman dan pemberi kekebalan tanaman terhadap hama dan penyakit.

Kitin dan kitosan sudah lama dikenal dan penelitian tentang pemanfaatannya masih terus berlangsung. Hal ini sesuai dengan prinsip konsep Blue economy dari Kementerian Kelautan dan Perikanan (KKP) yang merupakan alternatif konsep ekonomi dan diaplikasikan pada sektor perikanan dan kelautan berdasarkan lima prinsip utama, yaitu: (1) efisiensi sumber daya alam (2) zero waste (3) melibatkan aspek sosial (4) sistem produksi yang terus berputar dan (5) inovasi dan adaptasi (KKP dalam Sismaraini, 2015).

Secara spesifik, prinsip konsep Blue economy untuk melibatkan aspek sosial dapat dilakukan dengan melibatkan masyarakat pesisir dalam kegiatan-kegiatan 
yang berhubungan dengan kelautan dan perikanan. Pelibatan masyarakat pesisir dalam hal ini untuk kegiatan pengolahan limbah perikanan diharapkan akan mampu memberikan nilai ekonomis dan meningkatkan pendapatan masyarakat yang selama ini berprofesi sebagai nelayan maupun buruh kerja di perusahaan pengolahan udang yang ada disekitarnya. Pelibatan masyarakat pesisir ini juga sesuai dengan Nawa Cita No.6 yang bertujuan meningkatkan produktivitas rakyat dan daya saing di pasar internasional sehingga bangsa Indonesia bisa maju dan bangkit bersama bangsa-bangsa Asia lainnya, dan Nawa Cita No.7 Mewujudkan kemandirian ekonomi dengan menggerakkan sektorsektor strategis ekonomi domestik melalui pembinaan calon wirausaha baru (Bappenas, 2014).

Pengolahan limbah kulit udang dan rajungan pada dasarnya merupakan sebuah inovasi untuk memanfaatkan bahan buangan/limbah kulitsisapengolahanudang dan rajungan. Hasil temuan di lapangan menunjukkan bahwa potensi limbah kulit udang dan kulit rajungan di lokasi penelitian (Kabupaten Banyuwangi dan Kabupaten Situbondo) sangat melimpah. Hal ini dapat diketahui dari banyaknya perusahaan tambak udang maupun tambak udang yang dikelola oleh masyarakat. Di Kabupaten Banyuwangi terdapat 41 tambak udang baik milik perorangan maupun perusahaan dimana produksinya mencapai sekitar 1.957 ton/tahun, dari besarnya produksi udang tersebut $60 \%$ berupa kulit dan kepala yang biasanya dibuang dan pemanfaatannya masih sebatas sebagai pakan ikan (DKP Kab. Banyuwangi, 2018). Di Kabupaten Situbondo produksi udang tahun 2017 mencapai 7.827,348 ton. Di Kabupaten Situbondo terdapat perusahaan pengawetan udang skala besar yaitu PT. Panca Mitra Multi Perdana yang berlokasi di Kapongan (DKP Kab. Situbondo, 2018). Upaya pengolahan limbah kulit udang dan rajungan di Kabupaten Banyuwangi dan Kabupaten Situbondo diharapkan mampu menambah variasi produk hasil perikanan yang secara ekonomi akan menambah pendapatan masyarakat dari nilai tambah produk yang dihasilkan. Nilai tambah adalah pertambahan nilai yang terjadi karena satu komoditi mengalami proses pengolahan, pengangkutan dan penyimpanan dalam satu proses produksi (penggunaan/pemberian input fungsional) (Hayami dkk., 1987). Selain nilai tambah yang diharapkan dari sebuah proses pengolahan produk, sebuah usaha tidak terlepas dari investasi, pembiayaan dan perolehan pendapatan. Sebuah usaha juga harus diketahui perkembangan usaha yang dijalan sehingga perlu dilakukan analisis kelayakan usaha secara finansial. Investasi, pembiayaan, pendapatan maupun analisis kelayakan usaha merupakan sistem kerja yang membentuk sebuah struktur usaha.

Permasalahan yang dihadapi adalah limbah kulit udang dan rajungan sejauh ini belum dimanfaatkan untuk diolah menjadi produk yang memiliki nilai jual tinggi (dalam hal ini limbah kulit udang dan rajungan diolah menjadi pupuk dan kitin). Dengan demikian, maka diperlukan sebuah kajian tentang kelayakan finansial pengolahan limbah kulit udang dan rajungan yang gunanya untuk melihat layak tidaknya pengolahan ini dilakukan dan juga perhitungan besarnya nilai tambah yang dihasilkan dari proses perubahan bahan baku limbah kulit udang dan rajungan menjadi produk pupuk dan kitin, sehingga akan didapatkan gambaran besaran keuntungan perusahaan yang menjalankan kegiatan pengolahan tersebut. Tujuan penelitian ini adalah (1) untuk menganalisis kelayakan finansial usaha pengolahan limbah kulit udang dan rajungan dan (2) untuk menganalisis nilai tambah dan keuntungan perusahaan yang dihasilkan dari proses pengolahan kulit udang dan rajungan. 


\section{Tinjauan Pustaka}

\section{a. Pengembangan Inovasi Pengolahan Limbah Kulit Udang Dan Kulit Rajungan}

Rajungan (Portunus Pelagicus) tergolong hewan dasar pemakan daging yang termasuk dalam famili portunidae. Saat ini rajungan merupakan komoditas ekspor unggulan hasil perikanan Indonesia, khususnya untuk ekspor ke Jepang, Uni Eropa, dan Amerika Serikat. Meningkatnya permintaan ekpor berdampak pada volume produksi rajungan yang terus naik. Peningkatan produksi akan diikuti dengan peningkatan jumlah limbah yang dihasilkan, baik limbah padat berupa cangkang atau kulit dan limbah cair berupa air rebusan (Haryati, 2005). Menurut Multazam (2002), dalam satu ekor rajungan menghasilkan limbah proses yang terdiri dari 57\% cangkang, 3\% body reject, dan air rebusan $20 \%$. Rajungan dengan bobot 100-350 gram, menghasilkan limbah cangkang rajungan antara 51-150 gram. Jika produksi rajungan mencapai $600 \mathrm{~kg} /$ hari menghasilkan daging rajungan $250 \mathrm{~kg}$ sedangkan $350 \mathrm{~kg}$ merupakan limbah padat berupa capit dan cangkang.

Limbah cangkang rajungan dan kulit udang akan berdampak terhadap pencemaran lingkungan apabila tidak ditangani. Chasanah dan Barus (1994) menemukan bahwa $40 \%$ bagian dari udang dapat dikonsumsi dan sisanya adalah cangkang dan kepala. Limbah kulit udang/rajungan yang selama ini belum dimanfaatkan bahkan sering dianggap sebagai salah satu sumber polusi oleh manusia, bahkan ada pabrik pengolahan udang di Indonesia yang membuang kulit udang per hari sekitar 7 ton ke laut, karena kulit udang tersebut dianggap sebagai limbah yang dikhawatirkan akan mencemari lingkungan dan mendapat protes dari pemerintah dan masyarakat (Sismaraini, 2015).

Melihat besarnya limbah yang dihasilkan, diperlukan sebuah inovasi teknologi dalam pengolahannya. Selama ini hasil limbah laut yang berupa kulit udang, cangkang kerang, cangkang rajungan hanya dimanfaatkan sebagai campuran bahan terasi, makanan ternak dan juga untuk aksesoris, bahkan di beberapa daerah pesisir dibuang dan menimbulkan bau yang tidak sedap. Pengolahan kulit udang dan rajungan menjadi kitin dan kitosan merupakan inovasi dan menjadi peluang yang bisa menjadi nilai tambah dari limbah tersebut. Kitin dan kitosan merupakan sumber polimer terbarukan yang berasal dari kulit udang, kulit rajungan dan kulit family crustacea lainnya yang memiliki manfaat besar dalam dunia pertanian, industri kimia, kesehatan dan makanan. Kadar kitin dalam berat udang berkisar antara $60-70 \%$ dan bila diproses menjadi kitosan menghasilkan yield 15-20\% (Wardaniati dan Setyaningsih, 2009). Kulit udang mengandung 15-20\% kitin dan kitosan sebesar 50\% dari kandungan kitin, kadar abu sebesar 20\% serta kadar protein sebesar 35\% pada basis kering (Kelly et al. 2005 dalam Rini 2010). Manfaat Kitosan secara umum dapat digunakan untuk pengawet alami berbagai produk pangan seperti bakso, sosis, nuget, jus buah/sayur, tahu, ikan asin, mie basah, produk olahan ikan, buah-buahan, mayonise, dodol, dll karena memiliki aktifitas antimikroba dan antioksidan. Kitin dan Kitosan juga bermanfaat dalam bidang pertanian sebagai promotor pertumbuhan tanaman dan pemberi kekebalan tanaman terhadap hama dan penyakit.

Pengolahan limbah kulit udang dan cangkang rajungan menjadi kitin dan kitosan merupakan solusi dalam menanggulangi masalah pencemaran lingkungan. Demikian juga dari hasil samping proses pengolahan kitin dan kitosan tersebut akan dapat dihasilkan protein konsetrat/protein isolat yang sangat berguna untuk bahan campuran pembuatan 
pakan dan pupuk organik cair.

Dukungan Pemerintah tentang kitin dan kitosan sudah ada dan tercantum dalam Peraturan Presiden Republik Indonesia No 28 tahun 2008 tentang Kebijakan Industri Nasional, yaitu industri kitin dan kitosan adalah bagian dari agroindustri khususnya industri produk perikanan dan kelautan yang terklaster sebagai industri prioritas untuk pengembangan industri di Indonesia tahun 2015. Tujuan jangka panjang terkait dengan pengembangan industri kitin dan kitosan tersebut adalah pengembangan industri bioteknologi yang berbasis produk hasil laut, seperti kosmetika dan farmasi. Sementara itu, pada tujuan jangka menengah diharapkan agar industri hasil laut dan perikanan akan fokus untuk meningkatkan pemanfaatan limbah produk hasil laut dan perikanan menjadi produk yang memiliki nilai seperti kitin, kitosan dan gelatin (Sismaraini, 2015).

\section{Metode Penelitian}

Penelitian ini merupakan penelitian deskriptif dengan pendekatan kuantitatif. Penelitian dilakukan pada bulan FebruariSeptember 2018 dengan lokasi penelitian di Kabupaten Situbondo dan Banyuwangi. Informan penelitian pada usaha pengolahan limbah udang dan rajungan berasal dari 2 kabupaten yaitu Kabupaten Situbondo dan Kabupaten Banyuwangi. Informan dari Kabupaten Situbondo terdiri dari Dinas Lingkungan Hidup Kabupaten Situbondo, Dinas Kelautan dan Perikanan Kabupaten Situbondo, Universitas Abdurachman Saleh Situbondo, dan 8 orang anggota KUB Kilensari. Sedangkan informan dari Kabupaten Banyuwangi terdiri dari Dinas Lingkungan Hidup Kabupaten Banyuwangi, Dinas Kelautan dan Perikanan Kabupaten Banyuwangi, Badan Pemberdayaan Masyarakat dan Desa Kabupaten Banyuwangi, 2 orang pendamping KUB, Politeknik Negeri Banyuwangi, Universitas Airlangga Banyuwangi, Kepala Desa
Bomo Kecamatan Blimbingsari, Camat Kecamatan Blimbingsari, 5 orang anggota KUB Bomo dan 5 orang anggota KUB Ketapang.

Teknik pengumpulan data dengan cara Focus Group Discussion (FGD) dan pengisian kuesioner. FGD digunakan untuk mengumpulkan data primer mengenai hal-hal yang berkaitan dengan potensi dan upaya pengembangan pengolahan limbah udang dan rajungan, Kuesioner digunakan untuk memperoleh informasi secara lebih detail dari segi finansial usaha yang dijalankan. Analisis data terdiri dari (1) analisis nilai tambah produk hasil pengolahan limbah udang dan rajungan dan (2) analisis kelayakan finansial usaha pengolahan limbah udang dan rajungan.

Penentuan besarnya nilai tambah dari produk olahan perikanan yang dikaji secara dilakukan menggunakan metode Hayami tahun 1987. Secara matematis fungsi nilai tambah (NT) menurut Hayami et al (1987) dapat dirumuskan sebagai berikut :

$N T=f(K, B, T, H, U, h, L)$

dimana $K$ merupakan kapasitas produksi, $B$ adalah Jumlah bahan baku yang digunakan (kg), $T$ adalah Jumlah tenaga kerja yang dibutuhkan (orang), $H$ adalah harga output $(\mathrm{Rp} / \mathrm{kg}), U$ ialah Upah kerja (Rp), $h$ adalah Harga bahan baku (Rp/ kg), dan $L$ adalah Nilai input lain $(\mathrm{Rp} / \mathrm{kg})$

Analisis kelayakan finansial digunakan untuk mengukur potensi hasil pengembangan inovasi teknologi pengolahan limbah udang dan rajungan. Analisis kelayakan finansial usaha pengolahan limbah udang dan rajungan terdiri dari Net Present Value (NPV), ReturnCost Ratio (Rasio R/C), IRR (Internal Rate Of Return) dan PP (Payback Periods) (Tabel 1).

\section{a. NPV (Net Present Value)}

NPV atau nilai sekarang bersih adalah jumlah nilai sekarang dari manfaat bersih. Kriteria keputusan yang lebih 
Tabel 1. Metode Hayami yang Dimodifikasi

\begin{tabular}{|c|c|c|c|}
\hline No & Variabel & Satuan & Nilai \\
\hline 1. & Harga Beli Bahan & $\mathrm{Rp} / \mathrm{kg}$ & (1) \\
\hline 2. & Harga Jual Produk & $\mathrm{Rp} / \mathrm{kg}$ & (2) \\
\hline 3. & $\begin{array}{l}\text { Total Nilai Tambah per } \mathrm{kg} \\
\text { Output }\end{array}$ & $\mathrm{Rp} / \mathrm{kg}$ & $(3)=(2)-(1)$ \\
\hline \multicolumn{4}{|c|}{ Output, Input dan Harga } \\
\hline \multirow[t]{2}{*}{4.} & a. Output (volume penjualan) & $\mathrm{kg}$ & (4a) \\
\hline & b. Output (Nilai penjualan) & $\mathrm{Rp}$ & (4b) \\
\hline 5. & Bahan Baku Pokok & $\mathrm{Rp}$ & (5) \\
\hline 6. & Tenaga Kerja Langsung & HOK (Hr Org Krj) & (6) \\
\hline 7. & Faktor Konversi & & $(7)=(4 b) /(5)$ \\
\hline 8. & Koefisien T. Kerja Langsung & $\mathrm{Rp} / \mathrm{HOK}$ & $(8)=(4 b) /(6)$ \\
\hline 9. & Upah Tenaga Kerja Langsung & $\mathrm{Rp}$ & (9) \\
\hline \multicolumn{4}{|c|}{ Penerimaan dan Nilai Tambah } \\
\hline \multirow[t]{2}{*}{10.} & Biaya Input lain (Produksi) & $\mathrm{Rp}$ & (10a) \\
\hline & Biaya Input lain (Operasional) & $\mathrm{Rp}$ & $(10 b)$ \\
\hline \multirow[t]{2}{*}{11.} & Nilai tambah & $\mathrm{Rp}$ & $(11 a)=(4 b)-(5+10 a+10 b)$ \\
\hline & Rasio Nilai Tambah & $\%$ & $(11 b)=(11 a) /(4 b)$ \\
\hline \multicolumn{4}{|c|}{ Balas Jasa Pemilik Faktor Produksi } \\
\hline \multirow[t]{3}{*}{12} & Marjin & $\mathrm{Rp}$ & $(12)=(4 b)-(5)$ \\
\hline & Sumbangan biaya input lain & $\%$ & $(12 b)=(10 a+10 b) /$ \\
\hline & Keuntungan perusahaan & $\%$ & $\begin{array}{l}(12)^{*} 100 \% \\
(12 \mathrm{~b})=(11 \mathrm{a}) /(12)^{*} 100 \%\end{array}$ \\
\hline
\end{tabular}

Sumber: Hayami et al (1987)

baik adalah nilai NPV yang positif dan alternatif yang mempunyai NPV tertinggi pada peringkat pertama. Secara matematis, NPV dapat dituliskan (Abelson dalam Saputra dkk, 2011) :

$$
\mathrm{NPV}=\sum_{t=1}^{\mathrm{I}} \frac{\mathrm{Bt}-\mathrm{Ct}}{(1+\mathrm{i}) \mathrm{t}}
$$

Dimana B adalah manfaat ke t, $\mathrm{C}$ adalah biaya ke t, i merupakan Suku bunga (discount rate) per tahun, dan $\mathrm{t}$ adalah jangka waktu perhitungan, dan $\mathrm{n}$ adalah Jumlah tahun.

Kriteria NPV yaitu :

- NPV positif, maka investasi diterima;

- NPV negatif, sebaiknya investasi ditolak

\section{b. (Rasio R/C) Return-Cost Ratio}

Analisis kelayakan usaha perikanan jaring cumi dilakukan dengan melakukan analisis Return-Cost (Rasio
R/C). Analisis Return-Cost (Rasio $\mathrm{R} / \mathrm{C}$ ) adalah perbandingan antara total pendapatan dan total biaya dari suatu usaha. Analisis ini dilakukan untuk menganalisis performa usaha yang dikaji melalui pendapatan usahanya. Hasil perhitungan rasio $\mathrm{R} / \mathrm{C}$ akan diketahui probability keuntungan/ kerugian dan kelayakan usaha perikanan yang dijalankan. secara sistematis dituliskan :

$$
\begin{aligned}
\operatorname{Profit}(\pi) & =\mathrm{TR}-\mathrm{TC} \ldots \ldots \ldots \ldots \ldots \\
& =(\mathrm{p} . \mathrm{C})-(\mathrm{FC}+\mathrm{VC}) . \\
\operatorname{Rasio} \mathrm{R} / \mathrm{C} & =\mathrm{TR} / \mathrm{TC} \ldots \ldots \ldots \ldots \ldots
\end{aligned}
$$

Dimana, $\pi$ adalah Profit (Rp), TR adalah total revenue / pendapatan total (Rp), TC adalah total cost / biaya total (Rp), FC merupakan fixed cost / biaya tetap total (Rp), VC adalah variable cost / biaya variabel total (Rp), p adalah harga ikan ( $\mathrm{Rp} / \mathrm{Kg})$, dan $\mathrm{C}$ merupakan 
total tangkapan $(\mathrm{Kg})$

Adapun kriteria hasil perhitungan ratio $\mathrm{R} / \mathrm{C}$ adalah :

- Jika $\mathrm{R} / \mathrm{C}$ ratio $>1$, maka usaha yang dijalankan mengalami keuntungan atau layak untuk dikembangkan.

- Jika $\mathrm{R} / \mathrm{C}$ ratio < 1 , maka usaha tersebut mengalami kerugian atau tidak layak untuk dikembangkan.

- Jika $\mathrm{R} / \mathrm{C}$ ratio = 1, maka usaha berada pada titik impas (Break Event Point).

Biaya tetap (fixed cost) terdiri dari biaya investasi dan biaya administrasi. Biaya tidak tetap (variabel cost) adalah biaya operasional (Tabel 2).

\section{c. IRR (Internal Rate Of Return)}

Internal Rate of Return (IRR) merupakan alat untuk mengukur tingkat pengembalian hasil intern.(Kasmir dan Jakfar, 2009) Secara matematis dirumuskan sebagai berikut :

$$
\operatorname{IRR}=i_{1}+\frac{N P V_{1}}{N P V_{1}-N P V_{2}}\left(i_{2}-i_{1}\right)
$$

Dimana $i_{1}$ adalah Tingkat bunga 1 (tingkat discount rate yang menghasilkan NPV 1),

$\mathrm{i}_{2}$ merupakan Tingkat bunga 2 (tingkat discount rate yang menghasilkan
$\mathrm{NPV}_{2}$ ), $\mathrm{NPV}_{1}$ adalah Net Present Value $1, \mathrm{NPV}_{2}$ merupakan Net Present Value 2.

Kriteria IRR yaitu :

IRR > tingkat bunga relevan, maka investasi dikatakan menguntungkan IRR < tingkat bunga relevan, maka investasi dikatakan merugikan

\section{d. PP (Payback Periods)}

Payback period merupakan periode yang diperlukan untuk menutup kembali pengeluaran investasi. Secara sederhanan dapat dituliskan:

Payback period $=\frac{\text { Nilai Investasi }}{\text { Kas masuk bersih }} \times 1$ tahum

Menurut Kasmir dan Jakfar (2009), metode PP(Paybackperiod) merupakan teknik penilaian terhadap jangka waktu (periode) pengembalian investasi suatu proyek atau usaha.

Kriteria :

- Nilai payback period kurang dari 3 tahun kategori pengembalian cepat

- Nilai payback period 3 - 5 tahun kategori pengembalian sedang

- Nilai payback period lebih dari 5 tahun kategori lambat.

Tabel 2. Komponen Biaya Tetap dan Biaya Tidak Tetap Usaha Pengolahan Limbah Udang dan Rajungan

\begin{tabular}{llll}
\hline & Biaya Tetap (fixed cost) & \multicolumn{1}{c}{$\begin{array}{c}\text { Biaya Operasional (variabel } \\
\text { cost } \text { ) }\end{array}$} \\
\hline Biaya Investasi & \multicolumn{1}{c}{ Biaya } & \multicolumn{1}{c}{ Biaya } & \multicolumn{1}{c}{ Biaya Operasional } \\
& pemeliharan & Administrasi & \\
\hline Pabrik & Gedung & ljin usaha & Air \\
Peralatan & Peralatan & Pajak bangunan & Gas//kayu bakar \\
D a n d a $\mathrm{g} g$ & Dandang perebus & Pajak kendaraan & Konsumsi \\
perebus air & air & & Tenaga kerja \\
Ember & Ember & Bahan Baku \\
Pengaduk kayu & Loyang pengering & Bahan Tambahan \\
Alat peniris & Alat peniris & KOH \\
Gayung & & HCL \\
Sarung tangan & & Kompos \\
Gelas ukur & & Abu gosok \\
& & Zeolit \\
& & Dolomit \\
& & Tepung kulit udang/rajungan \\
& & Raw phosphat \\
\hline
\end{tabular}


Asumsi dalam penelitian digunakan sebagai batasan permasalahan penelitian. Beberapa asumsi yang digunakan dalam penelitian yaitu :

1. Penerimaan hanya didapatkan dari penjualan hasil tangkapan;

2. Pada tahun ke-0 umur usaha merupakan pembelian untuk investasi;

3. Modal yang digunakan merupakan modal sendiri dan tidak ada kredit/ pinjaman dari Bank atau yang lain;

4. Menggunakan discount rate $17,50 \%$ dengan dasar sesuai dengan tingkat bunga untuk usaha mikro Bank BUMN Pemerintah sampai Maret 2018;

5. Pada tahun ke-1 hingga tahun ke-10 penerimaan, modal, biaya tetap dan biaya tidak tetap mengalami kenaikan $3,18 \%$ setiap tahunnya berdasarkan tingkat inflasi nasional bulan Juli 2018.

\section{Hasil dan Pembahasan}

\section{A. Gambaran Umum Lokasi Penelitian 1. Kabupaten Situbondo}

Kabupaten Situbondo merupakan salah satu Kabupaten di Jawa Timur yang letaknya berada di ujung Timur pulau Jawa bagian Utara dengan posisi di antara $7^{\mathrm{O}} 35^{\prime}-7^{\mathrm{O}} 44^{\prime}$ Lintang Selatan dan $113^{\circ} 30-114^{\mathrm{O}} 42$ Bujur Timur. Kabupaten Situbondo berbatasan dengan Selat Madura di sebelah utara, di sebelah timur berbatasan dengan Selat Bali, di sebelah selatan berbatasan dengan Kabupaten Bondowoso dan Banyuwangi, serta di sebelah barat berbatasan dengan Kabupaten Probolinggo. Kabupaten Situbondo terdiri dari 17 Kecamatan, yaitu: Sumbermalang, Jatibanteng, Banyuglugur, Besuki, Suboh, Mlandingan, Bungatan, Kendit, Panarukan, Situbondo, Mangaran, Panji, Kapongan, Arjasa, Jangkar, Asembagus, dan Banyuputih. Luas Kabupaten Situbondo adalah $1.638,50 \mathrm{~km}^{2}$ atau $163.850 \mathrm{Ha}$, bentuknya memanjang dari Barat ke Timur lebih kurang $150 \mathrm{~km}$. Hasil Proyeksi Penduduk 2016, penduduk Kabupaten
Situbondo berjumlah 673.282 jiwa terdiri dari 328.279 jiwa laki-laki dan 345.003 jiwa perempuan, sehingga memiliki angka rasio sex sebesar 95,15 yang berarti bahwa dari 100 penduduk perempuan terdapat 95 penduduk laki-laki (BPS Kab. Situbondo, 2018).

\section{Kabupaten Banyuwangi}

Kabupaten Banyuwangi terletak diantara 743'-8 $46^{\prime}$ Lintang Selatan dan 113 $53^{\circ}$ $114^{\circ} 38^{\prime}$ Bujur Timur. Kabupaten Banyuwangi sebelah Utara berbatasan dengan Kabupaten Situbondo, sebelah timur berbatasan dengan Selat Bali, sebelah selatanberbatasan dengan Samudera Hindia, sebelah barat berbatasan dengan Kabupaten Bondowoso dan Kabupaten Jember. Luas wilayah Kabupaten Banyuwangi $5.782,50 \mathrm{~km}^{2}$ dan merupakan Kabupaten terluas di Provinsi Jawa Timur. Kabupaten Banyuwangi memiliki panjang garis pantai sekitar 175,8 km, serta Pulau sejumlah 10 buah. Kabupaten Banyuwangi terbagi atas dataran tinggi berupa daerah pegunungan, yang menghasilkan produksi perkebunan. Daerah dataran menghasilkan tanaman pangan, serta daerah sekitar garis pantai yang membujur dari arah utara ke selatan merupakan daerah penghasil berbagai biota laut. Kabupaten Banyuwangi terdiri dari 24 Kecamatan, 217 Desa/ Kelurahan, 838 Dusun/Lingkungan, serta 2.839 RW dan 10.569 RT. Hasil Proyeksi Penduduk 2016, penduduk Kabupaten Banyuwangi berjumlah 1.599.811 jiwa terdiri dari 795.976 jiwa laki-laki dan 803.835 jiwa perempuan, sehingga memiliki angka rasio sex sebesar 99 yang berarti bahwa dari 100 penduduk perempuan terdapat 99 penduduk laki-laki (BPS Kab. Banyuwangi, 2018).

\section{B. Usaha Pengolahan Limbah Udang dan Rajungan \\ 1. Investasi Usaha Pengolahan Limbah Udang dan Rajungan}

Pengeluaran biaya untuk usaha pengolahan limbah udang dan rajungan 
terdiri dari biaya yaitu biaya investasi dan operasional. Choliq et al dalam Wijaya dkk(2012) menyebutkan bahwa biaya investasi merupakan seluruh biaya yang dikeluarkan mulai usaha tersebut dilaksanakan sampai usaha tersebut mulai beroperasi. Kebutuhan investasi untuk usaha pengolahan limbah udang dan rajungan terdiri dari pabrik, dandang, ember, pengaduk, peniris, gayung, sarung tangan, gelas ukur, loyang pengering, biaya pemeliharaan dan biaya administrasi. Investasi usaha pengolahan limbah udang dan rajungan disajikan pada Tabel 3.

Usaha pengolahan limbah udang dan rajungan merupakan usah berskala kecil dengan jumlah tenaga kerja 5-8 orang. Besar investasi usaha pengolahan limbah udang dan rajungan adalah $\mathrm{Rp}$ 13.366.000,-. Investasi merupakan modal awal untuk menjalankan sebuah usaha. Investasi merupakan pengeluaran atau perbelanjaan penanaman-penanaman modal atau perusahaan untuk membeli barangbarang modal dan perlengkapan produksi untuk menambah kemampuan produksi barang-barang dan jasa-jasa yang tersedia dalam perekonomian (Sukirno, 2003). Suprapto (2007) menyebutkan bahwa dua hal penting dalam pengertian investasi yaitu mengandung makna bahwa investasi terjadi jika terdapat penambahan modal riil yang akan menambah kemampuan produksi, yang kedua adalah investasi memungkinkan penambahan pendapatan dimasa yang akan datang.

2. Pembiayaan dan Pendapatan Usaha Pengolahan Limbah Udang dan Rajungan

Pembiayaan dalam usaha pengolahan limbah udang dan rajungan diwujudkan dalam bentuk biaya tetap dan biaya operasional. Choliq dkk dalam Wijaya dkk (2012), biaya produksi adalah seluruh biaya yang dikeluarkan karena berlangsungnya proses produksi yang terdiri dari biaya tetap dan biaya tidak tetap. Jenis biaya

Tabel 3. Investasi Usaha Pengolahan Limbah Udang dan Rajungan

\begin{tabular}{lllll}
\hline No & Jenis Investasi & Uraian & Harga satuan & Nilai \\
\hline 1 & Pabrik & 1 Unit & 6.000 .000 & 6.000 .000 \\
2 & Peralatan & 2 Unit & 400.000 & 800.000 \\
& Dandang & 4 Unit & 55.000 & 220.000 \\
& Ember & 2 Unit & 12.000 & 24.000 \\
& Pengaduk & 2 Unit & 28.000 & 56.000 \\
& Peniris & 2 Unit & 10.000 & 20.000 \\
& Gayung & 10 Unit & 10.000 & 100.000 \\
& Sarung tangan & 2 Unit & 20.000 & 40.000 \\
& Gelas Ukur & 2 Unit & 28.000 & 56.000 \\
3 & Loyang Pengering & & & \\
& Pemeliharaan & 1 kali tahun & 3.000 .000 & 3.000 .000 \\
& Pabrik & 2 kali setahun & 50.000 & 100.000 \\
& Dandang & 2 kali setahun & 20.000 & 40.000 \\
& Ember & 1 kali tahun & 50.000 & 50.000 \\
& Loyang Pengering & 2 kali setahun & 50.000 & 100.000 \\
4 & Peniris & & & \\
& Administrasi & 1 kali tahun & 300.000 & 300.000 \\
& Ijin usaha & 1 kali tahun & 60.00 & 60.000 \\
& PBB & 1 kali tahun & 1.500 .000 & 1.500 .000 \\
Total & Pajak kendaraan & & & \\
\hline
\end{tabular}

Sumber : Pengolahan Data (2018) 
tetap (fixed cost) terdiri dari biaya pemeliharaan, biaya administrasi dan biaya penyusutan. Biaya tidak tetap (variable cost) yang dikeluarkan terdiri dari biaya operasional. Untuk pendapatan didefinisikan sebagai banyaknya penerimaan yang dinilai dengan satuan mata uang yang dapat dihasilkan dalam periode tertentu (Reksoprayitno, 2004). Pendapatan dalam usaha pengolahan limbah udang dan rajungan berupa penerimaan dari nilai hasil penjualan produk yang dihasilkan yaitu pupuk organik dan pupuk cair.

Biaya tetap ( $f$ ix cost) pada usaha pengolahan limbah udang dan rajungan terdiri dari biaya penyusutan, biaya pemeliharaan dan biaya administrasi yaitu sebesar Rp 6.208.236,-. Biaya penyusutan selama setahun dari usaha pengolahan limbah udang dan rajungan sebesar $\mathrm{Rp}$ 1.058.236,-. Biaya pemeliharaan selama setahun sebesar

Tabel 4. Pembiayaan dan Pendapatan Usaha Pengolahan Limbah Udang dan Rajungan

\begin{tabular}{lrr}
\hline \multicolumn{1}{c}{ Deskripsi } & Rp & \multicolumn{1}{c}{} \\
\hline Pendapatan Total & 506.313 .600 & \\
Biaya Total & 253.530 .636 & 100,00 \\
Biaya Tetap & $\mathbf{6 . 2 0 8 . 2 3 6}$ & $\mathbf{2 , 4 5}$ \\
Biaya Penyusutan & 1.058 .236 & 0,42 \\
- Pabrik & 205.151 & 0,08 \\
- Dandang & 136.767 & 0,05 \\
- Ember & 188.055 & 0,07 \\
- Pengaduk & 20.515 & 0,01 \\
- Peniris & 47.868 & 0,02 \\
- Gayung & 34.192 & 0,01 \\
- Sarung tangan & 341.918 & 0,13 \\
- Gelas ukur & 34.192 & 0,01 \\
- Loyang pengering & 49.578 & 0,02 \\
Biaya Pemeliharaan & 3.290 .000 & 1,30 \\
Biaya administrasi & 1.860 .000 & 0,73 \\
Biaya operasional & $\mathbf{2 4 7 . 3 2 2 . 4 0 0}$ & $\mathbf{9 7 , 5 5}$ \\
Bahan baku & 14.976 .000 & 5,91 \\
Air & 18.720 .000 & 7,38 \\
Gas/Kayu bakar & 11.232 .000 & 4,43 \\
Konsumsi & 23.400 .000 & 9,23 \\
Tenaga kerja & 109.200 .000 & 43,07 \\
KOH & 37.440 .000 & 14,77 \\
HCL & 9.984 .000 & 3,94 \\
Kompos & 19.656 .000 & 7,75 \\
Abu gosok & 17.690 .400 & 6,98 \\
Zeolit & 7.987 .200 & 3,15 \\
Dolomit & 5.990 .400 & 2,36 \\
Tepung & 4.492 .800 & 1,77 \\
Raw phosphat & 1.965 .600 & 0,78 \\
Keuntungan (profit) & $\mathbf{2 5 2 . 7 8 2 . 9 6 4}$ & \\
Sur & & \\
\hline
\end{tabular}


Rp 3.290.000,- dan biaya administrasi selama setahun sebesar Rp 1.860.000. Biaya tidak tetap (variable cost) pada usaha pengolahan limbah udang dan rajungan berupa biaya operasional selama setahun yaitu sebesar $\mathrm{Rp}$ 247.322.400,-. Total pendapatan yang diperoleh selama setahun sebesar Rp 506.313.600,- (Tabel 4).

\section{Kelayakan Finansial Usaha} Pengolahan Limbah Udang dan Rajungan

Untuk menghitung nilai bersih dari sebuah investasi saat ini, berdasarkan pada diskon yang tersedia dan juga pada serangkaian pembayaran dan pemasukan dimasa yang akan datang maka dilakukan penghitungan NPV suatu usaha, sedangkan untuk melihat keuntungan relatif yang akan didapatkan dalam sebuah usaha dilakukan perhitungan $\mathrm{R} / \mathrm{C}$ ratio (Damayanti, 2017). Analisis Net Present Value (NPV) dan RevenueCost Ratio (R/C Ratio) dalam usaha pengolahan limbah udang dan rajungan dapat dilihat pada Tabel 5 .

Berdasarkan Tabel 5 menunjukkan bahwa hasil perhitungan $\mathrm{Net}$
Present Value (NPV) adalah Rp 1.337.679.463,- atau NPV > 0, dengan demikian usaha ini layak untuk diusahakan. Soeharto (2002), semakin tinggi NPV suatu usaha, maka semakin baik pula usaha tersebut dan usaha yang dapat menaikkan keuntungan yaitu yang mempunyai NPV lebih besar. Perhitungan Revenue-Cost Ratio (Rasio R/C) menunjukkan bahwa usaha pengolahan limbah udang dan rajungan adalah layak untuk dikembangkan yaitu dengan nilai rasio $\mathrm{R} / \mathrm{C}$ 1,751. Nilai rasio $\mathrm{R} / \mathrm{C}$ tersebut juga menunjukkan setiap pengeluaran Rp. 1.000,00 akan memperoleh pendapatan sebesar Rp. 1.751,00. Rasio R/C > 1 juga menunjukkan usaha yang dijalankan sudah efisien (Sari, 2011).

Perhitungan IRR (Internal Rate Of Return) usaha pengolahan limbah udang dan rajungan disajikan pada Tabel 6. Berdasarkan Tabel 6 menunjukkan bahwa nilai IRR adalah 35,05\%. Jika dibandingkan dengan tingkat bunga relevan yaitu $17,50 \%$ maka nilai IRR > tingkat bunga relevan sehingga investasi yang

Tabel 5. $N P V$ dan $R / C$ Ratio Usaha Pengolahan Limbah Udang dan Rajungan

\begin{tabular}{|c|c|c|c|c|c|c|}
\hline Tahun & Investasi & Benefit & Total Cost & Net Benefit & $\begin{array}{c}\text { Discount } \\
\text { Rate } 17,50 \%\end{array}$ & NPV \\
\hline 0 & 6.208 .236 & 0 & 6.208 .236 & -6.208 .236 & 1 & -6.208 .236 \\
\hline 1 & & 506.313 .600 & 288.942 .636 & 217.370 .964 & 0,851 & 184.996 .565 \\
\hline 2 & & 522.414 .372 & 298.071 .863 & 224.342 .509 & 0,741 & 166.179 .636 \\
\hline 3 & & 539.027 .150 & 307.491 .401 & 231.535 .749 & 0,656 & 151.826 .721 \\
\hline 4 & & 556.168 .213 & 317.210 .479 & 238.957 .734 & 0,588 & 140.563 .373 \\
\hline 5 & & 573.854 .362 & 327.238 .624 & 246.615 .738 & 0,533 & 131.528 .393 \\
\hline 6 & & 592.102 .931 & 337.585 .665 & 254.517 .266 & 0,488 & 124.154 .764 \\
\hline 7 & & 610.931 .804 & 348.261 .741 & 262.670 .063 & 0,449 & 118.053 .961 \\
\hline 8 & & 630.359 .435 & 359.277 .316 & 271.082 .119 & 0,417 & 112.950 .883 \\
\hline 9 & & 650.404 .865 & 370.643 .187 & 279.761 .678 & 0,388 & 108.645 .312 \\
\hline 10 & & 671.087 .740 & 382.370 .492 & 288.717 .248 & 0,364 & 104.988 .090 \\
\hline NPV & & & & & & 1.337 .679 .463 \\
\hline $\mathrm{R} / \mathrm{C}$ & & & & & & 1,751 \\
\hline
\end{tabular}

Sumber: Data Primer Diolah, 2018 
Tabel 6. Perhitungan IRR Usaha Pengolahan Limbah Udang dan Rajungan

\begin{tabular}{cccc}
\hline Tahun & Benefit & Cost & Net Benefit \\
\hline 0 & 0 & 6.208 .236 & -6.208 .236 \\
1 & 506.313 .600 & 288.942 .636 & 217.370 .964 \\
2 & 522.414 .372 & 298.071 .863 & 224.342 .509 \\
3 & 539.027 .150 & 307.491 .401 & 231.535 .749 \\
4 & 556.168 .213 & 317.210 .479 & 238.957 .734 \\
5 & 573.854 .362 & 327.238 .624 & 246.615 .738 \\
6 & 592.102 .931 & 337.585 .665 & 254.517 .266 \\
7 & 610.931 .804 & 348.261 .741 & 262.670 .063 \\
8 & 630.359 .435 & 359.277 .316 & 271.082 .119 \\
9 & 650.404 .865 & 370.643 .187 & 279.761 .678 \\
10 & 671.087 .740 & 382.370 .492 & 288.717 .248 \\
\hline IRR & & \multicolumn{2}{c}{35.05} \\
\hline
\end{tabular}

Sumber : Data Primer Diolah, 2018

dilakukan dikatakan menguntungkan. Hal ini sesuai dengan pernyataan Kasmir dan Jakfar (2009) yaitu IRR > tingkat bunga relevan maka investasi dikatakan menguntungkan.

Usaha pengolahan limbah udang dan rajungan merupakan usaha yang mendatangkan keuntungan karena usaha ini memanfaatkan sisa pengolahan perikanan (udang dan rajungan) yang dianggap sebagai limbah dan tidak dimanfaatkan, sehingga harga bahan baku yang digunakan masih murah. Selain itu, proses produksinya relatif mudah dan memerlukan investasi usaha yang kecil sehingga mudah dijalankan.

Analisis Payback Periods (PP) pada usaha pengolahan limbah udang dan rajungan dapat dilihat pada Tabel 7 . Nilai PP diperoleh sebesar 2,1. Nilai Payback Period kurang dari 3 tahun kategori pengembalian cepat. Setelah usaha dijalankan lebih dari 2,1 tahun ( \pm 2 tahun 1 bulan), maka usaha sudah mulai mendatangkan hasil dan keuntungan. Jika dilihat dari jangka waktu pengembalian investasinya termasuk dalam kategori pengembalian cepat karena kurang dari 3 tahun. Hal ini sesuai dengan pernyataan Kasmir dan Jakfar (2009) yang menyatakan bahwa jika payback period kurang dari 3 tahun maka termasuk kategori cepat. Jangka waktu pengembalian investasi tergolong cepat karena sarana dan prasarana produksi yang dibutuhkan relatif murah dan sedikit, harga bahan baku murah dan harga produk yang dihasilkan tinggi. Sarana dan prasarana yang dibutuhkan berbiaya rendah dan jumlah sedikit menjadikan pengeluaran untuk biaya investasi relatif sedikit yaitu Rp 6.208.236,-. Untuk biaya operasional, harga bahan baku murah karena bahan baku utama merupakan limbah sisa pengolahan yang masih jarang dimanfaatkan. Hal ini dapat menekan biaya yang dikeluarkan untuk operasional yaitu sebesar Rp 146.078.964,- per tahun. Pendapatan usaha yang diperoleh selama setahun besar karena harga jual produk yang tinggi, sehingga mampu menutup biaya investasi dan operasional yang dikeluarkan. Hal inilah yang mendatangkan keuntungan atau profit bagi usaha pengolahan limbah udang dan rajungan dan dapat digunakan untuk pengembalian investasi. 
Tabel 7. Perhitungan PP Usaha Pengolahan Limbah Udang dan Rajungan

\begin{tabular}{llllclcc}
\hline Tahun & Benefit & Total Cost & Net Benefit & $\begin{array}{c}\text { Discount } \\
\text { Rate } \\
\mathbf{1 7 , 5 0 \%}\end{array}$ & PV Benefit & Saldo & $\begin{array}{c}\text { (Saldo/ } \\
\text { PV } \\
\text { Benefit) }\end{array}$ \\
\hline 0 & 0 & 6.208 .236 & -6.208 .236 & 1 & -6.208 .236 & -6.208 .236 & $\mathbf{1}$ \\
1 & 506.313 .600 & 288.942 .636 & 217.370 .964 & 0,851 & 184.996 .565 & 178.788 .330 & $\mathbf{0 , 0}$ \\
2 & 522.414 .372 & 298.071 .863 & 224.342 .509 & 0,741 & 166.179 .636 & 351.176 .202 & $\mathbf{1 , 1}$ \\
3 & 539.027 .150 & 307.491 .401 & 231.535 .749 & 0,656 & 151.826 .721 & 318.006 .357 & 2,3 \\
4 & 556.168 .213 & 317.210 .479 & 238.957 .734 & 0,588 & 140.563 .373 & 292.390 .093 & 2,3 \\
5 & 573.854 .362 & 327.238 .624 & 246.615 .738 & 0,533 & 131.528 .393 & 272.091 .766 & 2,2 \\
6 & 592.102 .931 & 337.585 .665 & 254.517 .266 & 0,488 & 124.154 .764 & 255.683 .157 & 2,2 \\
7 & 610.931 .804 & 348.261 .741 & 262.670 .063 & 0,449 & 118.053 .961 & 242.208 .725 & 2,2 \\
8 & 630.359 .435 & 359.277 .316 & 271.082 .119 & 0,417 & 112.950 .883 & 231.004 .844 & 2,1 \\
9 & 650.404 .865 & 370.643 .187 & 279.761 .678 & 0,388 & 108.645 .312 & 221.596 .195 & 2,1 \\
10 & 671.087 .740 & 382.370 .492 & 288.717 .248 & 0,364 & 104.988 .090 & 213.633 .402 & 2,1 \\
\hline PP & & & & & & & 2,1 \\
\hline SP
\end{tabular}

Sumber: Data Primer Diolah, 2018

Usaha pengolahan limbah udang dan rajungan merupakan usaha yang berhasil karena tingkat pengembalian yang tinggi/cepat. Hal ini sesuai dengan pernyataan Irkhami (2010) yang menyebutkan bahwa penilaian keberhasilan investasi ditentukan oleh tingkat pengembalian yang tinggi. Cashflow usaha pengolahan limbah udang dan rajungan disajikan pada lampiran I.

\section{Nilai Tambah Pengolahan Limbah Udang dan Rajungan}

Usaha pengolahan limbah udang dan rajungan pada dasarnya adalah pemanfaatan bahan sisa dari usaha pengolahan udang dan rajungan. Dengan kata lain, usaha ini merupakan sebuah usaha untuk mendapatkan nilai tambah dari suatu produk sisa yang belum dimanfaatkan sebelumnya. Menurut Purwaningsih (2015), nilai tambah adalah selisih dari nilai output dengan biaya bahan dan pengolahan input. Nilai tambah adalah pertambahan nilai yang terjadi karena suatu komoditi mengalami proses pengolahan, pengangkutan dan penyimpanan dalam suatu proses produksi, dari proses diatas maka bertambah pula pemanfaatannya, harga jual maupun fungsinya. Nilai tambah dipengaruhi oleh faktor teknis dan faktor non teknis. Informasi atau keluaran yang diperoleh dari hasil analisis nilai tambah adalah besarnya nilai tambah, rasio nilai tambah, margin dan balas jasa yang diterima oleh pemilik faktor produksi (Hayami dkk., 1987). Hasil analisis nilai tambah selama satu tahun menunjukkan marjin sebesar Rp 508.809.600,- yang didistribusikan untuk masing-masing faktor yaitu sumbangan biaya input lain $22,570 \%$ dan keuntungan perusahaan $77,430 \%$ atau dengan kata lain tiap pengolahan $1 \mathrm{~kg}$ limbah udang dan rajungan menjadi pupuk organik diperoleh marjin sebesar Rp 624.000,-; pupuk cair diperoleh margin sebesar Rp 1.248.000,- dan kitin diperoleh margin $\mathrm{Rp}$ 107.328.000,-. Untuk perhitungan nilai tambah usaha pengolahan limbah udang dan rajungan per tahun disajikan pada Tabel 9. 
Tabel 9. Perhitungan Nilai Tambah Produk Hasil Pengolahan

Limbah Udang dan Rajungan Per Tahun

\begin{tabular}{|c|c|c|c|c|}
\hline & Variabel & Satuan & keterangan & Nilai \\
\hline 1. & Harga Beli Bahan & $\mathrm{Rp} / \mathrm{kg}$ & & 1.872 .000 \\
\hline \multirow[t]{3}{*}{2.} & Harga Jual Produk & $\mathrm{Rp} / \mathrm{kg}$ & Pupuk organik & 2.496 .000 \\
\hline & & Rp/liter & Pupuk cair & 3.120 .000 \\
\hline & & $\mathrm{Rp} / \mathrm{kg}$ & Kitin & 109.200 .000 \\
\hline \multirow[t]{3}{*}{3.} & Total Nilai Tambah per kg Output & $\mathrm{Rp} / \mathrm{kg}$ & Pupuk organik & 624.000 \\
\hline & & Rp/liter & Pupuk cair & 1.248 .000 \\
\hline & & $\mathrm{Rp} / \mathrm{kg}$ & Kitin & 107.328 .000 \\
\hline I. & Output, Input dan Harga & & & \\
\hline \multirow[t]{6}{*}{4.} & a. Output (volume penjualan) & $\mathrm{kg}$ & Pupuk organik & 9.391 \\
\hline & & liter & Pupuk cair & 32.448 \\
\hline & & $\mathrm{kg}$ & Kitin & 312 \\
\hline & b. Output (Nilai penjualan) & $\mathrm{Rp}$ & Pupuk organik & 75.129 .600 \\
\hline & & $\mathrm{Rp}$ & Pupuk cair & 324.480 .000 \\
\hline & & $\mathrm{Rp}$ & Kitin & 109.200 .000 \\
\hline 5. & Bahan Baku Pokok & & & 14.976 .000 \\
\hline 6. & Tenaga Kerja Langsung & HOK (Hr Org Krj) & & 312 \\
\hline 7. & Faktor Konversi & & & 33,975 \\
\hline 8. & Koefisien T. Kerja Langsung & $\mathrm{Rp} / \mathrm{HOK}$ & & 1.630 .800 \\
\hline & Upah Tenaga Kerja Langsung & $\mathrm{Rp}$ & & 109.200 .000 \\
\hline \multicolumn{5}{|c|}{ II. Penerimaan dan Nilai Tambah } \\
\hline & a. Biaya Input lain (Produksi) & $\mathrm{Rp}$ & & 105.206 .400 \\
\hline & b. Biaya Input lain (Operasional) & $\mathrm{Rp}$ & & 6.252 .000 \\
\hline \multirow[t]{2}{*}{11.} & a. Nilai tambah & $\mathrm{Rp}$ & & 382.375 .200 \\
\hline & b. Rasio Nilai Tambah & $\%$ & & 75,151 \\
\hline \multicolumn{5}{|c|}{ III. Balas Jasa Pemilik Faktor Produksi } \\
\hline \multirow[t]{3}{*}{12} & Marjin & $\mathrm{Rp}$ & & 493.833 .600 \\
\hline & a. Sumbangan biaya input lain & $\%$ & & 22,570 \\
\hline & b. Keuntungan perusahaan & $\%$ & & 77,430 \\
\hline
\end{tabular}

Sumber: Data Primer Diolah, 2018

\section{Simpulan}

Kesimpulan hasil penelitian adalah (1) finansial usaha pengolahan limbah kulit udang dan rajungan menunjukkan bahwa usaha ini layak dijalankan dengan tingkat pengembalian hasil $35,05 \%$ dan periode pengembalian pengeluaran investasi 2,1 tahun. (2) Perhitungan nilai tambah pengolahan limbah kulit udang dan rajungan adalah $\mathrm{Rp}$ 382.375.200,-/tahun dengan rasio nilai tambah $75,151 \%$ dan marjin keuntungan perusahaan $77,430 \%$. Bagi Pemerintah Daerah (melalui Dinas Kelautan dan Perikanan Provinsi Jawa Timur, Kabupaten Banyuwangi dan Kabupaten Situbondo) memperluas jangkauan sosialisasi dan pelatihan pengolahan limbah kulit udang dan rajungan maupun limbah pengolahan hasil laut lain yang belum termanfaatkan menjadi produk yang memiliki nilai jual. (1) Bagi Pemerintah Daerah (melalui Dinas Kelautan dan Perikanan Provinsi Jawa Timur, Kabupaten Banyuwangi dan Kabupaten Situbondo) memberikan pendampingan lanjutan kepada Kelompok Unit Binaan (KUB) yang telah mendapat pelatihan tentang pengolahan limbah kulit udang dan rajungan agar tetap menjalankan kegiatan produksinya. (2) Bagi Pemerintah Daerah (melalui Dinas Kelautan dan Perikanan Provinsi Jawa Timur, Kabupaten Banyuwangi dan Kabupaten Situbondo) melakukan sosialisasi dan pembinaan agar tidak hanya melakukan pengolahan produk kelautan dan perikanan dari bentuk segar menjadi bentuk olahan tetapi juga berinovasi memanfaatkan bahan buangan/limbah dari hasil pengolahan menjadi produk yang memiliki nilai jual. (3)Bagi KUB : melakukan penambahan volume dan sarana produksi untuk meningkatkan kapasitas, output produk dan menambah pendapatan dari pemanfaatan limbah kulit udang dan rajungan. 


\section{Ucapan Terima Kasih}

Penulis mengucapkan terimakasih kepada Badan Penelitian dan Pengembangan Provinsi Jawa Timur yang telah memberikan dukungan finansial berupa dana penelitian tahun anggaran 2018. Terimakasih juga penulis sampaikan kepada Dinas Kelautan dan Perikanan Provinsi Jawa Timur, Dinas Perikanan Kabupaten Situbondo, Dinas Perikanan dan Pangan Kabupaten Banyuwangi atas dukungan pada kegiatan ini. Serta tak lupa kepada masyarakat kelompok sasaran peserta pelatihan dan pihak-pihak yang tidak dapat penulis tulis satu persatu.

\section{Daftar Pustaka}

Badan Perencanaan Pembangunan Nasional. (2014). Rencana Pembangunan Jangka Menengah Nasional 2015-2019. Jakarta : Bappenas.

Badan Pusat Statistik Kabupaten Banyuwangi. (2018). Banyuwangi dalam Angka Tahun 2017. Banyuwangi: BPS Kab. Banyuwangi.

Badan Pusat Statistik Kabupaten Situbondo. (2018). Situbondo dalam Angka Tahun 2017. Situbondo : BPS Kab. Situbondo.

Badan Pusat Statistik Provinsi Jawa Timur. (2016). Jawa Timur dalam Angka 2015. Surabaya : BPS Prov. Jatim.

Badan Pusat Statistik Provinsi Jawa Timur. (2017). Jawa Timur dalam Angka 2016. Surabaya : BPS Prov. Jatim.

Bank Indonesia. (2018). Laporan Inflasi (Indeks Harga Konsumen). https:// www.bi.go.id/id/moneter/inflasi/ data/Default.aspx, diakses 30 Juni 2018.
Bank Indonesia. (2018). Suku Bunga Dasar

Kredit. https://www.bi.go.id/id/ perbankan/suku-bunga-dasar, diakses 30 Juni 2018.

Chasanah, E. dan Barus, H. R. (1994). Komposisi Kimia Udang dan Ikan Demersal Perairan Laut Dalam. Jurnal Penelitian Perikanan Laut, 86: $42-47$.

Damayanti, H. O. (2017). Struktur Usaha Penangkapan Ikan oleh Nelayan Tradisional di Desa Pecangaan Kecamatan Batangan Kabupaten Pati. Jurnal Litbang XIII(2) :7384.

Dinas Kelautan dan Perikanan Kabupaten Banyuwangi. (2018). Laporan Akhir Kelautan dan Perikanan Tahun 2017. Banyuwangi : Dinas Kelautan dan Perikanan Kabupaten Banyuwangi.

Dinas Kelautan dan Perikanan Kabupaten Situbondo. (2018). Laporan Akhir Kelautan dan Perikanan Tahun 2017. Situbondo : Dinas Kelautan dan Perikanan Kabupaten Situbondo.

Haryati, S. (2005). Kajian Subsitusi Tepung Ikan Kembung, Rebon, Rajungan dalam Berbagai Konsentrasi Terhadap Mutu Fisika-Kimiawi dan Organoleptik pada Mei Instan. Skripsi. Fakultas Pertanian. Semarang : Universitas Semarang.

Hayami, Y., T. Kawageo, Morooka, Y. and Siregar, M. (1987). Agricultural Marketing And Processing In Upload Java : A Perspective From A Sunda Village. Bogor : The CPGRT Centre. 
Hidayat, S., Marimin, Suryani, A., Sukardi, dan Yani, M. (2012). Modifikasi Metode Hayami Untuk Perhitungan Nilai Tambah Pada Rantai Pasok Agroindustri Kelapa Sawit. Jurnal Teknologi Industri Pertanian, 22(1). 22-31.

Indrasti, N. S., Suprihatin dan Setiawan, W. K. (2012). The Combination of Chitosan-Nutmeg Extract For The Natural Antibacteria and Preservative Agents of Red Snapper (Lutjanus sp.) Fillet. Jurnal Teknologi Industri Pertanian, Vol. 22: 122-130.

Irkhami, N. Analisis Risiko dalam Investasi Islam. Jurnal Mustasid, Vol. 1 (2) : 209-225.

Kasmir dan Jakfar. (2009). Studi Kelayakan Bisnis. Jakarta: Kencana Prenada Media Group.

Multazam. (2002). Prospek Pemanfaatan Cangkang Rajungan (Portunus sp) Sebagai Suplemen Pakan Ikan. Skripsi. Fakultas Perikanan dan Ilmu Kelautan. Bogor : Institut Pertanian Bogor.

Mulyani, Ninik. (2016). Pengaruh Tingkat Pendapatan Terhadap Pola Konsumsi Masyarakat Dalam Perspektif Ekonomi Islam (Studi Kasus Desa Harapan Jaya Kecamatan Semendawai Timur Kabupaten Ogan Komering Ulu (OKU) Timur). Skripsi. Palembang : UIN Raden Fatah

Peraturan Presiden Republik Indonesia Nomor 28 Tahun 2008 tentang Kebijakan Industri Nasional.

Purwaningsih, R. (2015). Analisis Nilai
Tambah Produk Perikanan Lemuru Pelabuhan Muncar Banyuwangi. Jurnal Ilmiah Teknik Industri, Vol 14 No. 1 : 13-23.

Reksopriyatno. (2004). Sistem Ekonomi dan Demokrasi Ekonomi. Jakarta : Bina Grafika.

Rini I. (2010). Recovery dan Karakterisasi Kalsium dari Limbah Demineralisasi Kulit Udang Jerbung (Penaeus merguiensis deMan). Skripsi. Fakultas Perikanan dan Ilmu Kelautan. Bogor : Institut Pertanian Bogor.

Roza, Elviana. (2017). Maritim Indonesia, Kemewahan Yang Luar Biasa. https://kkp.go.id/artikel/2233maritim-indonesia-kemewahanyang-luar-biasa, diakses 9 Oktober 2018

Saputra, S. W.,A. Solichin, D. Wijayanto dan F. Kurohman, 2011. Produktivitas Dan Kelayakan Usaha Tuna Longliner Di Kabupaten Cilacap Jawa Tengah. Jurnal Saintek Perikanan, Vol 6 (2) : 84-91.

Sari, K. M, (2011). Analisis Usaha Pengolahan Ikan Asin di Kabupaten Cilacap. Skripsi. Jurusan Sosial Ekonomi Pertanian Program Studi Agrobisnis Fakultas Pertanian. Surakarta : Universitas Sebelas Maret.

Sismaraini D. (2015). Strategi Pengembangan Industri Kitin Dan Kitosan Di Indonesia. Tesis. Sekolah Pascasarjana Program Studi Teknologi Industri Pertanian. Bogor : Institut Pertanian Bogor.

Soeharto, I. (2002). Studi Kelayakan Proyek Industri. Jakarta : Erlangga. 
Sukirno, S. (2003). Ekonomi Macro. Jakarta : Raja Grafindo Persada.

Suprapto, Heru. (2007). Analisis Keputusan Investasi Bagi Usaha Mikro, Kecil dan Menengah (UMKM). JEMI, Vol. 7 No. 1 : 22-29.

Wardaniati, R. A. Dan Setyaningsih, S. (2009). Pembuatan Chitosan dari Kulit Udang dan Aplikasinya Untuk Pengawetan Bakso. eprints. undip.ac.id/1718/1/makalah_penelitian_ fix.pdf, diakses 12 Oktober 2018.

Wijaya, R. A., Huda, H. M. dan Manadiyanto. (2012). Penguasaan Aset dan Struktur Pembiayaan Usaha Penangkapan Tuna Menurut Musim yang Berbeda. Jurnal Sosial Ekonomi Kelautan dan Perikanan. Vol 7 (2) : 153- 163. 
ahun

1 Inflow

produk

Jumlah

2 Outflow

Biaya Tetap

pabrik

dandang

506.313 .600

522.414 .372

539.027 .150

556.168 .213

573.854 .36

592.102 .93

7

8

9

ember

pengaduk

136.767

205.151

205.151
136.767

188.055

141.116

$39.027 .150 \quad 556.168 .213$

573.854 .362

188.055

$$
20.515
$$

47.868

peniris

47.868

34.192

gayung

34.192

gls ukur

loyang

Biaya

Biaya

administrasi

Jumlah

Biaya tidak

tetap

bahan baku

air

gas

konsumsi

tng kerja

$\mathrm{KOH}$

HCL

341.918

\subsection{8}

34.192

49.578

34.192

49.578

3.290 .000

1.860 .000

6.208 .236

\subsection{0 .000}

1.860 .000

6.208 .236

14.976 .000

18.720 .000

11.232 .000

23.400 .000

109.200.000

37.440 .000

9.984 .000
194.035

21.167

49.391

35.279

352.791

35.279

51.155

3.394 .622

1.860 .000

6.346 .510

15.452 .237

19.315.296

11.589 .178

24.144 .120

38.630 .592

10.301 .491

$\begin{array}{rr}218.406 & 225.351 \\ 145.604 & 150.234 \\ 200.205 & 206.572 \\ 21.841 & 22.535 \\ 50.961 & 52.582 \\ 36.401 & 37.559 \\ 364.010 & 375.585 \\ 36.401 & 37.559 \\ 52.781 & 54.460 \\ 3.502 .571 & 3.613 .953 \\ 1.860 .000 & 1.860 .000 \\ 6.489 .181 & 6.636 .388 \\ & \\ 15.943 .618 & 16.450 .625 \\ 19.929 .522 & 20.563 .281 \\ 11.957 .713 & 12.337 .969 \\ 24.911 .903 & 25.704 .102 \\ 16.255 .547 & 119.952 .474 \\ 39.859 .045 & 41.126 .562 \\ 10.629 .079 & 10.967 .083\end{array}$

155.011

213.141

23.252

54.254

38.753

387.529

38.753

56.192

3.728 .876

1.860 .000

6.788 .278

16.973 .755

21.217 .194

12.730 .316

26.521 .492

123.766 .962

42.434 .387

11.315 .837

\subsection{1}

159.941

23.991

55.979

39.985

399.852

39.985

57.979

3.847 .455

1.860 .000

6.944 .997

17.513 .52

21.891 .900

13.135 .140

27.364 .875

127.702 .752

43.783 .801

11.675 .680
247.540

165.027

226.912

24.754

57.759

41.257

412.567

41.257

59.822

3.969 .804

1.860 .000

7.106 .700

18.070 .450

22.588.063

13.552 .838

28.235 .078

131.763 .699

45.176 .126

12.046.967
$630.359 .435 \quad 650.404 .865$

650.404 .865

671.087 .740

671.087 .740 
136 | Ratna Dewi Judhaswati dan Herna Octivia Damayanti, Kelayakan Usaha Pengolahan Limbah Kulit

\begin{tabular}{|c|c|c|c|c|c|c|c|c|c|c|c|}
\hline Kompos & & 19.656 .000 & 20.281 .061 & 20.925 .999 & 21.591 .445 & 22.278 .053 & 22.986 .495 & 23.717 .466 & 24.471 .681 & 25.249 .881 & 26.052 .827 \\
\hline abu gosok & & 17.690 .400 & 18.252 .955 & 18.833 .399 & 19.432 .301 & 20.050 .248 & 20.687 .846 & 21.345 .719 & 22.024 .513 & 22.724 .893 & 23.447 .544 \\
\hline Zeolit & & 7.987 .200 & 8.241 .193 & 8.503 .263 & 8.773 .667 & 9.052 .669 & 9.340 .544 & 9.637 .573 & 9.944 .048 & 10.260 .269 & 10.586 .546 \\
\hline Dolomit & & 5.990 .400 & 6.180 .895 & 6.377 .447 & 6.580 .250 & 6.789 .502 & 7.005 .408 & 7.228 .180 & 7.458 .036 & 7.695 .202 & 7.939 .909 \\
\hline $\begin{array}{l}\text { Tepung } \\
\text { Raw }\end{array}$ & & 4.492 .800 & 4.635 .671 & 4.783 .085 & 4.935 .187 & 5.092 .126 & 5.254 .056 & 5.421 .135 & 5.593 .527 & 5.771 .401 & 5.954 .932 \\
\hline Phosphat & & 1.965 .600 & 2.028 .106 & 2.092 .600 & 2.159 .145 & 2.227 .805 & 2.298 .650 & 2.371 .747 & 2.447 .168 & 2.524 .988 & 2.605 .283 \\
\hline $\begin{array}{l}\text { Jumlah } \\
\text { Total }\end{array}$ & & 282.734 .400 & 291.725 .354 & 301.002 .220 & 310.574 .091 & 320.450 .347 & 330.640 .668 & 341.155 .041 & 352.003 .771 & 363.197 .491 & 374.747 .172 \\
\hline Outflow & 6.208 .236 & 288.942 .636 & 298.071 .863 & 307.491 .401 & 317.210 .479 & 327.238 .624 & 337.585 .665 & 348.261 .741 & 359.277 .316 & 370.643 .187 & 382.370 .492 \\
\hline Net Benefit & -6.208 .236 & 217.370 .964 & 224.342 .509 & 231.535 .749 & 238.957 .734 & 246.615 .738 & 254.517 .266 & 262.670 .063 & 271.082 .119 & 279.761 .678 & 288.717 .248 \\
\hline DF $17,50 \%$ & 1 & 0,851 & 0,741 & 0,656 & 0,588 & 0,533 & 0,488 & 0,449 & 0,417 & 0,388 & 0,364 \\
\hline NPV & & & & & & 1.337 .679 .463 & & & & & \\
\hline $\mathrm{R} / \mathrm{C}$ & & & & & & 1,751 & & & & & \\
\hline IRR & & & & & & 35,05 & & & & & \\
\hline PP & & & & & & 2,1 & & & & & \\
\hline
\end{tabular}

